\title{
Malformation: Impending Danger in Mango Cultivation
}

\author{
Rajnee Sharma, Ashish Sharma, Jai Singh" and T. R. Sharma \\ Jawaharlal Nehru Krishi Vishwa Vidyalaya Jabalpur (M.P.), India \\ *Corresponding author:
}

\section{A B S T R A C T}

\begin{tabular}{|c|c|}
\hline & \multirow{4}{*}{$\begin{array}{l}\text { Mango (Mangifera indica L.) is an important fruit crop in India and honored as } \\
\text { king of fruit in the country. Among the several abiotic and biotic factors, } \\
\text { mango malformation is the most serious disease causes up to } 60 \text { per cent yield } \\
\text { losses and confines the mango cultivation in tropical and subtropical countries } \\
\text { of the worldwide. Mango malformation expresses two types of symptoms on } \\
\text { plant i.e. vegetative and floral malformation, in which floral malformation is } \\
\text { very virulent and causes the loss of entire crop than the vegetative one. } \\
\text { Initially the epidemiology of mango malformation is not clearly understood } \\
\text { and conflict reports regarding the causal agent existed. While, many studies } \\
\text { have proven that fungus Fusarium moniliforme var. subglutinans is dominant } \\
\text { pathogen responsible for mango malformation disease and their control yet to } \\
\text { be resolved. Hence, the objective of present reviews at offering a clear and } \\
\text { complete picture of the various aspects of development and management of } \\
\text { mango malformation. }\end{array}$} \\
\hline $\begin{array}{l}\text { Mango } \\
\text { malformatiom, } \\
\text { Fusarium } \\
\text { moniliforme var. } \\
\text { subglutinans, } \\
\text { Vegetative } \\
\text { malformation and } \\
\text { floral malformation }\end{array}$ & \\
\hline Article Info & \\
\hline & \\
\hline
\end{tabular}

\section{Introduction}

Mango (Mangifera indica $\mathrm{L}$ ) is an Indian sub continent originated fruit crop (Mukehrjee and Litz, 2011) and belongs to family Anacardiaceae. It has been cultivated more than 4000 years ago and has a wide genetic diversity with great cultural and religious significance (Popenoe, 1932 and Purseglove, 1972). Mango occupies an eminent place amongst fruit crops and is acknowledged as 'King of fruits' in the country (Purseglove, 1972). India ranks the first among world's mango producing countries. It has contributed to 57.18 per cent of the total world production with 19.22 million tones (Negi, 2000). Despite India's share of $57.18 \%$ in world's mango production, its productivity is very low when compared to other mango producing countries.

Mango is a complicated tree and it is always confusing to understand its pattern of vegetative and reproductive growth and its various problems. These problems are largely associated with unavailability of quality scion and rootstock. 


\section{Geographical distribution}

The Mango malformation was first time reported by Maries (Watt, 1891) at Darbhanga in Bihar, India. Since then it has been reported from Israel and Maxico (Malo and Mc Millan, 1972; Verma et al., 1974), Malaysia, Pakistan (Khan and Khan, 1960), Bangladesh (Meah and Khan, 1992) and United Arab Emirates (Burhan, 1991), South Africa (Schwartz, 1968), Sudan (Minessey et al., 1971), Swaziland, Uganda, Egypt (Atiah, 1955), Brazil (Flechumann et al., 1970), Cuba (Padron Soroa, 1983), United State of America (Malo and Mc Millan, 1972; Ploez et al., 2002), Australia (Peterson, 1986) and Sultanate of Oman (Kvas et al., 2008).

Incidence of mango malformation is recorded from all part of the country but it is more prevalent in north- western part than the southern part and north -eastern of the country (Varma, 1969 and Majumdar and Sharma, 1990). In Punjab, the incidence of malformation is the highest (Singh et al., 1940). It is widespread in Uttar Pradesh (Singh and Chakrarvarthi, 1935) and negligible in Bihar (Mallik, 1959) and Maharashtra (Burns, 1910). In Gujarat (Burns and Prayag, 1920), the extent is quite higher in the northern districts. Recently it is also reported from Jammu and Kashmir (Chib et al., 1984) , Himachal Pradesh (Sharma and Badiyala, 1990) Madhya Pradesh (Mishra, 2004), Haryana (Mehta et al., 1986)and Andhra Pradesh (Kulkarni, 1979).

\section{Losses}

Globally, it has been identified that there are number of problems faced in mango production. These problems are largely associated with unavailability of quality scion and rootstock. Malformation is the most threatening malady that causes great economic loss ranged from 5-80\%
(Srivastava, 1998 and Ginai, 1965) and limits the mango production in India (Kumar and Chakrabarti, 1997) and tropical and subtropical countries around the globe (Ploetz, 2001). In India, 86 per cent mango orchards are affected from malformation, however, in South Africa only 73 per cent with 1-70 per cent of disease severity (Kumar et al., 1993). The malformations are characterized by a compact mass of hermaphrodite flowers, greenish in colour, stunted in growth and remain unproductive. The malformed panicles remain intact on the trees for a considerable time period (Hifney et al., 1978). Floral malformation, in contrast to vegetative one, is very virulent and can cause the loss of the entire crop due to abort the fruits shortly after they have set; hence, the yield of mango crop reduced by as much as 50-80 per cent (Kumar et al., 2011).

\section{Symptoms}

Mango malformation affects the leaf panicles and inflorescence leading to the massive reduction in yield and induces two types symptoms i.e., vegetative malformation and floral malformation (Verma, 1983).

\section{Vegetative Malformation}

Vegetative malformation is more commonly seen on young seedlings in nursery (Ploetz et al., 2002; Youssef et al., 2007). Infected seedlings give rise to small shoot let's bearing small scaly leaves with a bunch like appearance on shoot apex. Many such shoots may be produced and form a bunch hence, it is also known as bunchy top (Bhatnagar and Beniwal, 1977; Kanwar and Nijjar, 1979). The seedlings, in the early stage which become malformed, remain stunted and die while the seedlings which are infected later attain normal growth above the malformed areas (Singh et al., 1961; Kumar and Beniwal, 1992, Ploetz and Freeman, 2009; Chakrabarti, 
2011; Freeman et al., 2014). Symptoms of vegetative malformation include hypertrophied, tightly bunched young shoots with swollen apical and lateral buds. Vegetative growth occurs in several intermittent flushes, separated by resting periods with no apparent growth (Davenport, 2009; Hernandez Delgado et al., 2011; Ramirez et al., 2014).

\section{Floral malformation}

Floral malformation, in contrast to vegetative one, is very virulent and can cause the loss of the entire crop. Affected panicles either do not set fruits or abort shortly after they have set, hence, could reduce the yield by $50-80$ per cent (Kumar et al., 2011). Floral malformation targets the panicles, is the most destructive as it affects trees at the bearing stage (Ploetz, 2001; Youssef et al., 2007; Ploetz and Freeman, 2009; Chakrabarti, 2011). The malformed panicles are compact and overcrowded due to larger flowers and looks like a compact mass and are more green and sturdy and it bends down due to its own weight. These infected panicles do not set fruits (Ploetz, 2001; Youssef et al., 2007; Ploetz and Freeman, 2009; Chakrabarti, 2011). They remain as black masses of dry tissue during summer but some of them continue to grow till the next season. It directly affects the productivity. Such panicles have numbers of flowers that remain unopened and are mostly staminate and rarely bisexual (Singh et al., 1961; Schlosser, 1971; Hiffny et al., 1978). The ovary of malformed bisexual flowers is exceptionally enlarged and non-functional with poor pollen viability (Mallik, 1963; Shawky et al., 1980). Both healthy and malformed panicles may appear on same panicle or on the same shoot. Embryo abortion occurs at a faster rate in the malformed flowers. The severity of malformation may vary on the same shoot from light to medium or heavy malformation of panicles (Varma et al., 1969a).

\section{Causal agents}

The etiology of mango malformation was not well understood (Kumar et al., 1993; and Ploetz et al., 2001). However, many studies have proven that Fusarium mangiferae is the pathogen responsible for mango malformation disease and Koch's postulates have been completed successfully with this fungus in various countries worldwide (Kumar et al., 1993). Although the cause of malformation has been controversial, the evidence of fungal pathogen, and eriophyid mite has been suggested by various workers (Hassan, 1944; Narasimhan, 1954). Besides these biotic factors the several abiotic factors viz., nutritional deficiency, physiological disorder and hormonal imbalance (Iyer et al., 2009 and Kumar et al., 1993) and Carbon / Nitrogen ratio of shoots for the causal agent of mango malformation (Tripathi, 1955; Mallik,1963) have also been suggested from time to time.

\section{Disease cycle}

Disease cycle of mango malformation was not well understood till date (Gamliel-Atinsky et al., 2009b; Kumar et al., 1993; Ploetz et al., 2001). The disease spread by grafting through which malformation is moved in new area ((Kumar et al., 1993). Primary spread has also been clearly demonstrated nursery (Prakash and Srivastava, 1987), infected nursery stock (Haggag, 2010) and mango bud mite. The presence of Aceria mangiferae, the mango bud mite, within buds increased frequency and severity of bud colonization by the pathogen, indicating that the bud mites may enhance fungal infection Gamliel-Atinsky et al., (2009a). However, dissemination of pathogen within-tree and tree-to-tree in nurseries and orchards is yet to be understood (Ploetz, 2004). Number of reports indicates that the disease moves slowly in infected orchards (Kumar and Beniwal, 1992). The pathogen did not survive for extended periods 
in soil under natural conditions and is not seed borne. Infected seedlings cultivated beneath trees were most likely affected by inoculums originating from mature panicles and not by systemic infections from soil borne inoculums since levels in the soil and lower stem sections were very low compared to levels in upper stem sections and apical meristems (Youssef, et al., 2007).

In recent years from studies, it evident that the malformed inflorescences serve as the primary source of inoculums which disseminate passively in the air as conidia are blown or fall from dry malformed inflorescences as dry debris. Conidia land on the foliage and reach the infection site, namely, the apical bud. Systemic colonization and infection by the fungus was not evident for this host-pathogen interaction, since there was no infection via roots or survival in soil, there was no continuum of colonization via the vascular tissues, and, the pathogen is concentrated within apical and lateral buds, only at but not between the nodes (Freeman et al., 2015). It was also reported that $F$. mangiferae remained viable in various parts of the trees for up to seven years, indicating that the pathogen survives for long periods in woody portions of the tree, however, only where lateral buds were present (Lahav et al., 2001). This further indicates that the pathogen infects locally, at the buds, and is not transferred systemically via the vascular system.

\section{Abiotic factors}

\section{Malformation with respect to season}

Seasonal variations in the occurrence and severity of malformation correlate with ambient temperature at flowering (Majumdar and Sinha, 1972). In Egypt panicles appearing on spring shoots are most severely affected (Shawky et al., 1980). In Florida the heaviest infection occurs under unusually wet conditions (Campbell and Marlatt, 1986). In India, the direction of disease gradient curves corroborated with the direction of rain drop drift in June-July (Kumar and Chakrabarti, 1997). The incidence of mango malformation has been found to vary from season to season. It is more prevalent in main flowering season the off flowering season (Majumdar and Sinha, 1972). This seasonal variation of disease incidence in mango is due to the environmental parameters, host metabolites and mangiferin content (Chakrabarti et al., 1997; Chakrabarti and Kumar, 1998). The disease development was prompted by high rainfall but affected by high temperature and bright sunlight. As regard the height, the malformed seedlings initially were taller than the healthy ones.

\section{Malformation with respect to temperature}

The temperature apparently has a key role in disease development. In India, the mango malformation is present in all mangoproducing areas (Verma et al., 1971), with a lower incidence in the southern and eastern than in the northern region where mean temperature during flowering remains between $10-15^{\circ} \mathrm{C}$. It is mild where corresponding temperature is $15-20^{\circ} \mathrm{C}$, sporadic at $20-25^{\circ} \mathrm{C}$ and nil over the $25^{\circ} \mathrm{C}$. This trend is also reflected in the world distribution of the disorder and its incidence is mainly recorded where mean temperature during winter is $<16^{0} \mathrm{C}$. However, the temperature does not appear to have a significant role when symptoms have already developed on the panicles, because affected panicles continue to grow and producing excessive growth in dry hot summer (Verma et al., 1969a-c).Earlier emerging floral buds are the most severely damaged, whereas later ones escape the disease (Kumar et al., 1993). Escape was attributed to the occurrence of relatively high temperature during panicle 
development. Coincidentally, a study of seasonal variation of the population density of $F$. moniliforme on mango shoots indicated that spore density reached a maximum in February, when temperature ranged from 8 to $27^{\circ} \mathrm{C}$ and the humidity was $85 \%$, and that a decline of spore density coincided with hot, dry conditions (Kumar et al., 1993). Majumdar and Sinha (1972) reported that the incidence of mango malformation has been found to vary from season to season, but the causes of such variation are not well defined. However, it was observed that the variety Neelum, which had 59 per cent floral malformation in the normal flowering season (March), had only 4-5 per cent floral malformation in June flowering. Incidence of Mango malformation was observed to be 20 per cent at 400 meter altitude, while almost all plants were found to be free from floral malformation at an altitude of 1250 meter and above. Night temperature below $100 \mathrm{C}$ for long duration was found to be responsible for suppressing the incidence of floral malformation (Singh et al., 1999). Puttarudrih and Basavana (1961), Singh et al., (1992) and Chadha et al., (1979a) reported that the occurrence of malformation differed according to the age of plants. They recorded more disease in young plants than in older ones. Singh et al., (1961) concluded that about 91 per cent disease incidence was recorded in 4-8 years old plants and only 9.6 per cent in older plants. Age of flowering shoots also influence the incidence of floral malformation (Verma et al., 1983a)

\section{Malformation with respect to soil moisture}

Mango malformation is caused by excessive soil moisture. Because of vegetative activity during the fruiting period, inflorescences produced in April or later were changed into leafy structures (Burns, 1910). The disease was therefore held to be a physiological disorder (Burns and Prayag, 1920), not transmitted by fungi, insects, or through sap. In tropical conditions, flowering occurs after a period of drought. Water stress advances floral bud break by nearly two weeks in about $40 \%$ buds of mango. It stimulated growth of floral buds and delayed the vegetative buds. Low temperature after a period of drought has been shown to be beneficial for flower initiation (Schole field et al., 1986). Lu and Chacko (2000) and Tahir et al., (2003) reported that the controlled soil water deficit lasting five weeks was demonstrated to promote earlier and more intense flowering in mango trees. Further, they reported that flowering was found dependent on drought stress. Sharma et al., (2015) reported that increase in soil moisture content delayed the bud initiation and panicle emergence. The minimum intensity $\left(2.7 \mathrm{~m}^{2}\right)$ and severity $(24.7 \%)$ of malformation was recorded under restricted soil moisture conditions. The higher moisture content in soil increased the intensity $\left(4.5 \mathrm{~m}^{2}\right)$ and severity $(42.7 \%)$ of malformation. Planting direction of mango plant may also affect the malformation incidence. The panicles of north direction were most severely infested with malformation whereas, the canopy facing south direction was least infested with this malady.

\section{Malformation with respect to Plant nutrients}

Several attempts were made to apply nutrients to diseased trees to affect a cure and at the same time establish nutritional imbalance as a cause of the disorder, have had mixed results. In some cases, nutrient application has improved the nutritional status of the trees and led to increased fruit yield. However, inability to reproduce these results and the unconvincing rationale supporting the disease etiology detracted from the initial successes. It is found that very little differences in the mineral constituent of healthy and malformed 
tissue, however, micronutrient deficiency, especially iron and zinc have been reported to be associated with the causation of malformation (Abou El dahab, 1975; Martin Preveli et al., 1975; Minessey et al., 1971; Singh and Rajput, 1976). However, zinc sulphate alone or in combination with growth regulator (NAA) could not reduce the diseases incidence in Amrapali variety of Mango (Pandey and Pandey, 1997b). El_Beltagy et al., (1980) concluded that soil treatment with Bayfolan (containing, N, P, K, $\mathrm{Mn}, \mathrm{Fe}, \mathrm{Cu}, \mathrm{Mg}, \mathrm{B}, \mathrm{Zn}, \mathrm{Ca}$ and Mo) @ 100ml per tree in 22 years old mango tree cv. Taimour also did not affect the coverage of malformation. However, Singh et al., (1991) suggested that the vegetative malformation was found to be associated significantly with higher amounts of all nutrients except $\mathrm{Ca}$ which was significantly higher in healthy seedlings. Hence, point to lower $\mathrm{Ca}$ could be act as one of the pre-disposing factors causing malformation in mango (Singh et al., 1991). Singh et al., (1994) analyzed the contents of $\mathrm{Fe}, \mathrm{Zn}, \mathrm{Mn}, \mathrm{Cu}$ and $\mathrm{Co}$ in malformed and healthy panicles of mango leaves and shoots bearing fully swollen bud, bud inception, fully grown panicles prior to full bloom and at full bloom. They found that the concentrations of $\mathrm{Fe}, \mathrm{Zn}, \mathrm{Cu}, \mathrm{Mn}$ and $\mathrm{Co}$, in both malformed and healthy part of plant are not significantly differed to each other; hence, malformation in mango is not caused by the deficiency of these micronutrients.

Number of reports indicates that the shoots of malformed panicles had lower (Pandey et al., 1973, 1977) as well as higher (Mishra, 1976) levels of nitrogen than the healthy tissues. This is might be due to varietal response and varying soil conditions. Enhanced nitrogen application was found to reduce malformation incidence, whereas addition of Phosphorus and Potash increased the disease incidence significantly (Kanwar and Kahlon, 1987). The minimum number of malformed panicles and higher number of healthy panicles was observed in NPK treated plant. In addition, N (1000 g/ plant) P (750 g / plant) K (750 g / plant) treated plant exhibited higher length of healthy panicles. Moreover, NPK treatment showed lowest malformation intensity percentage as compared to other fertilizer treatments (Muhammad Azam et al., 2020). Application of NPK in 9:3:3 ratio is not curtail the disease severity and concluded that the malformation is not directly associated with nutritional imbalance (Bindra and Bakhetia, 1971) these may influence the incidence of the malady.

\section{Malformation with respect to Plant growth regulators}

The malformation was related to hormonal imbalance at flower bud differentiation (Jagirdar and Jafri. 1966). More recent reports (Kumar and Beniwal, 1992) indicate that hormonal imbalances in the malformed tissues are attributable to metabolic changes stemming from host-parasite interactions.

\section{Biotic factor}

Recently three major biotic factors are reported to be pathogen of mango malformation disease which is directly or indirectly responsible to spread disease incidence. These factors include eriophyid mites, viruses and fungi.

\section{Eriophyid mites}

Theory of mites as a causal agent of mango malformation came into light in 1944 when Hassan (1944) and Sayed (1946) reported the mite Aceria mangiferae from Egypt. Similar findings were also recorded in India by Narasimhan (1959) who, claimed eriophyid mite could be causal organism and found it inter and intracellular in the meristem and tender regions. Several species of mites, 
including predatory species, were reported to be associated with the disease (Singh, 1955, 1975; Narayana and Ghai, 1961, 1963). However, several other researchers suggested that there is no correlation of mite population and bud malformation incidence (Prasad et al., 1965, 1972; Labuschang et al., 1993). The role of mite in wounding and as an vector of fungus (Fusarium moniliformae var. sublguinans) was admitted by Summanwar (1967), Summanwar and Raychoudhury (1968) and Pinkas and Gazet (1992), Kumar et al., (1993),Ploetz et al., (1994) GamlielAtinsky et al., (2009).

\section{Viruses}

The Mango malformation occurs on both grafted and seedlings plants and incidence increases slowly, hence Sattar (1946) considered the mango malformation of viral nature. Mallik (1963) transmitted the disease successfully from branch to seedlings, seedlings to scions and seedlings to seedlings by grafting, budding, or by dodder and considered virus was the main cause of the diseases just after failure of physiological theory. Though, the findings of Singh et al., (1961), Kausar (1959), Prasad et al., (1965), Bindra and Bakhetia (1971), Beniwal and Bhatnagar (1975) were fail to transmit disease through grafting, budding, mechanical inoculation or through insect from branches to seedlings, seedlings to seedlings, seedlings to scions. The results thus obtained from these studies do not suggest that mango malformation is of viral etiology (Verma, 1983b).

\section{Fungus}

In India Summanwar et al., (1966) and Varma et al., (1969) were first time to report that the floral and vegetative malformation in mango was caused by Fusarium moniliforme (recognized later as $F$. subglutinans). Verma et al., (1969a, b, 1971, 1972, 1974a) consistently isolated fungus the Fusarium moniliformae from various parts of affected malformed plants and Koch's postulates have been completed successfully with this fungus in various countries worldwide (Crookes and Rijkenberg, 1985; Freeman et al., 1999; Kumar et al., 1993; Varma et al., 1974).

Today, it is well cited and confirmed that a fungus Fusarium moniliforme (Gibberella fujikuroi) var. subglutinans is the dominant causal agent of mango malformation (Campbell and Marlatt, 1986; Salazar- Garcia, 1995; and Kumar et al., 1997, Ploetz and Gregory, 1993 and Britz et al., 2002). Fusarium mangiferae has been identified in China, Egypt, India, Israel, Malaysia, Oman, South Africa, Spain, Sri Lanka and the USA, and appears to be the most common causal agent of MMD worldwide (Freeman et al., 2014c). A second mango malformation disease causal agent, $F$. sterilihyphosum, was described from South Africa (Britz et al., 2002) and Brazil (Lima et al., 2009), whiles another causal agent, $F$. mexicanum was described exclusively from Mexico (Otero Colina et al., 2010).

A fourth recently described species, $F$. tupiense sp. Nov. (Resembling $F$. sterilihyphosum), has been shown to cause malformation in Brazil (Lima et al., 2012), Senegal (Senghor et al., 2012) and Spain (Crespo et al., 2016). Most recently, $F$. pseudocircinatum has been described as an additional mango malformation disease causal agent in Mexico and the Dominican Republic (Freeman et al., 2014; Garcia Lopez et al., 2016). In addition, F. mangiferae, $F$. proliferatum, $F$. pseudocircinatum and other Fusarium species have been isolated from affected mango in Australia (Liew et al., 2016). All Fusarium species responsible for mango malformation disease cause similar disease symptoms. 


\section{Management}

Management measures of mango malformation shown inconsistency since a reduction in disease incidence was observed in some orchards but not in others (Chakrabarti, 1996). The scientists have been very keen to tackle the mysterious malformation through different methods viz., physical alteration, chemical spray, plant growth regulators, botanicals, and biocontrol agents. Some of the recent findings are targeted to decrease the incidence and increase the yield.

Table.1 Response of different mango cultivars against Mango malformation

\begin{tabular}{|c|c|c|}
\hline S.No. & Varieties with incidence $(\%)$ of malformation & References \\
\hline \multirow[t]{2}{*}{01} & $\begin{array}{l}\text { Collector, Langra and Neelum (2-8\%), Anwar Rataul (45- } \\
50 \%) \text {, Alphanso (70-95\%), Dusehri (15-69\%), MaIda (50- } \\
90 \%) \text {, Samar Bahisht (20-98\%). }\end{array}$ & Khan and Khan (1960) \\
\hline & $\begin{array}{l}\text { Amrapali }(57.12 \%), \text { Bombay Green }(56.25 \%), \text { Mallika } \\
(55.0 \%), \text { Langra }(9.37 \%) \text {, Totapuri }(16.53 \%) \text { and } \\
\text { Alphonso }(17.25 \%)\end{array}$ & $\begin{array}{l}\text { Badliya and } \\
\text { Lakhanpal (1990) }\end{array}$ \\
\hline 02 & $\begin{array}{l}\text { Bombay Green, Dashehari, Lucknow safeda and Chousa } \\
\text { showed } 10.8-24.2 \% \text { and Baramasi }(0.32-1.92 \%)\end{array}$ & Ram et al., (1990) \\
\hline 03 & $\begin{array}{l}\text { Neelum (17.39-29.24), Bangalora ( } 18.13-19.45 \%) \text { Kesar } \\
(15.39-18.49 \%) \text { and Krishnabhog }(9.6-10.23 \%) \text {, }\end{array}$ & Singh et al., (1994) \\
\hline 04 & $\begin{array}{l}\text { Kensington (19.2\%), Mallika (12.3\%), and Dashehari } \\
(4.6 \%)\end{array}$ & $\begin{array}{l}\text { Yadav and Singh } \\
\text { (1995) }\end{array}$ \\
\hline 05 & Resistant cultivars- Bhadauran, H-8-1, Ellaichi, Rataul & Singh et al., (2012) \\
\hline 07 & Tomy Atkin $(54-17 \%)$ & Sao-Jose et al., (2000) \\
\hline 08 & $\begin{array}{l}\text { Anwar Retaul (56.63\%), Chaunsa ( } 44.05 \%) \text {, Malda } \\
(43.05 \%) \text {, Dashehari }(36.73 \%) \text {, Langra( } 34.48 \%) \text { and } \\
\text { Sensation }(16.51 \%) \text {. }\end{array}$ & Ahmad et al., (2002) \\
\hline 09 & $\begin{array}{l}\text { Sindhri (36.24\%), Anwar Rataul (31.02\%) and Dusehri } \\
(26.83 \%)\end{array}$ & Iqbal, et al., (2004) \\
\hline 10 & $\begin{array}{l}\text { Lab-e-Mashooq' (68\%), G.M. Wala (64.28\%), 'Sensation' } \\
(7.2 \%) \text { and 'GulabKhas' (7.8\%). }\end{array}$ & Ishfaq et al., (2008) \\
\hline 11 & $\begin{array}{l}\text { Desi (46\%), Dashehari (38\%), Almas (34\%), Chaunsa } \\
(30.4 \%) \text { and Sindhri (26\%) Neelum }(22.0 \%) \text {, Langra } \\
(20.8 \%) \text {, Swarnarika (18\%), Siroli }(16 \%) \text { and Fajri }(14 \%) .\end{array}$ & $\begin{array}{l}\text { Khaskheli et al., } \\
\text { (2008) }\end{array}$ \\
\hline
\end{tabular}

\section{Host Resistance}

Severity of Mango malformation was varied from variety to variety and tree to tree of the same variety (Azzous et al., 1978; Nath et al., 1987, Soni et al., 2013). The early and mid season mango varieties showed lower incidence of the diseases than late blooming varieties (Nirvan, 1953; Singh et al., 1961; Khurana and Gupta, 1973). Monoembryonic mango cultivars like Dashaheri, langra, Chausa, Malda and Safeda and Polyembryonic like Carabao, Peach, Cecil and Turpentine were affected by malformation (Prasad, et. al., 1972). The degree of incidence of disease in various cultivars is presented in table 1, which indicated that none of the cultivar is completely resistant to malformation. Elaichi, Alib, and Bhadauran are completely free from 
this disorder but their fruit quality is not good hence their use is restricted to only for resistant (Singh et al., 2017).

\section{Selection of planting materials}

New Orchard should be established with pathogen-free nursery stock. Scion material should never be taken from an affected orchard, and affected plants that are observed in the nursery should be removed and destroyed. Nurseries should also not be established in orchards, especially where affected by malformation. This practice is common in Egypt and India, two of the most severely affected areas (Ploetz, 2001).

\section{Pruning}

Moderate pruning of $20 \mathrm{~cm}$ shoot bearing malformed panicles in the month of January at panicle emergence stage can be effective in suppressing the incidence of malformation in cv. Dashehari (Sirohi, et.al., 2009), which is usually very high in early emerging flower buds and panicles, (Singh, et al., 1974).

Pruning of shoot probably removes malformation inducing principle (Kumar et al., 1993) which accumulates at the shoot tip. Conventionally, affected terminals and the subtending three nodes are cut from trees, removed from the field and burned. If these measures are practiced for 2 or 3 consecutive years, the disease can be reduced to insignificant levels. Thereafter, the disease can be kept in check by removing symptomatic tissues every other year (Muhammad et.al., 1999; Ploetz, 2001). In south Africa, (Darvas, 1987) and United States (Campbell and Marlatt, 1986) the only control method recommended commercially is the pruning of infected branches while in Mexico, pruning after harvest at 80 and $30 \mathrm{~cm}$ from the affected zone maintained the lowest bud deformation(Lopez-Estrada et al., 2005).

\section{Nutrient management}

The nutrient application has improved the nutritional status of the trees and led to increased fruit yield. Partial control of malformation has recently been claimed in India by Chakrabarti, and Ghosal (1989), while these claims have also been refuted (Rajan, 1986), by spraying the diseased plant parts with mangiferin-Zn2+ and mangiferin$\mathrm{Cu} 2+$ chelates. The normal balance of mangiferin and micronutrients revived in the diseased tissues, and the population of Fusarium declined (Chakrabarti, and Ghosal (1989). In South Africa (Darvas, 1987) FM was effectively controlled and significantly higher fruit yields recorded after two years of trunk injection with phosetyl-AI $+\mathrm{Zn}+\mathrm{B}$ mixture.

The treatment significantly raised $\mathrm{Zn}$ levels in the leaves without effectively reducing Fs population in the MIs. A direct inhibitory effect of chemicals against the pathogen is inferred, together with secondary control through the improved nutritional status of trees.

The incidence of floral malformation was lowest $(20 \%)$ in trees treated with Rogor + Multiplex + urea and highest $(55.37 \%)$ in the non-treated trees. Similarly, the incidence of vegetative malformation was lowest $(6.5 \%)$ in trees treated with Rogor + Multiplex + urea compared with $28.12 \%$ in non-treated trees (Thakur et al., 2000).

The effect of different combinations of N, P and $\mathrm{K}$ on incidence of malformation of mango (Mangifera Indica. L), Cv. Dusheri was studied with each treatment of N (1000 g), P $(750 \mathrm{~g})$ and $\mathrm{K}(750 \mathrm{~g})$ was applied in soil during February and August, results indicates that the minimum number of malformed panicles and higher number of healthy panicles was observed in NPK treated plant. 


\section{Hormonal management}

The use of chemical substances as foliar application proved to be effective in reducing Mango malformation disease, because they may delayed or advanced the beginning of flowering (Shawky et al., 1978 and Nunez et $a l ., 1986)$. In addition, the application of GA3 at $50 \mathrm{ppm}$ reduced flower malformation of Taimour mango trees (Shawky et al., 1978 and Azzouz et al., 1980 and 1984).

Application of Naphthalene acetic acid at $100 \mathrm{ppm}$, or at $200 \mathrm{ppm}$ in October reduced the incidence of malformation in the following season particularly at the higher rate (Majumder et al., 1970, 1976 and Majumder and Diware, 1989; Mahrous, 2004). The incidence of floral malformation was reduced most by using NAA at $100 \mathrm{ppm}$ and also by IBA at $200 \mathrm{ppm}$ (Singh and Dhillon, 1986) prior to flower bud differentiation.

\section{Fungicides}

To date, no effective chemicals are available for disease control or for that matter for 'curing' infected trees. Among various fungicides, Prochloraz is an imidazole group of fungicide was the most efficient fungicide to decrease the disease incidence when applied at the interval of three weeks along with the removal of the malformed plant parts at regular intervals results in a notable decrease of incidence (Magaritha et al., 2018, Freemana et al., 2014)). The Spray of Benomyl 50 WP @2 $\mathrm{g} \mathrm{L}^{-1}$ water results in $70.37 \%$ reduction of disease incidence as compared to previous year (Zafar Iqbal1 et al., 2011).

\section{Antibiotics}

Isolated Streptomyces aureofaciens was chosen as antagonists to Fusarium moniliforme var. subglutinans, the causative agent of MMD. Bioactive metabolites secreted by $S$. aureofaciens were measured as growthreductions of $F$. moniliforme var. subglutinans.

The effectiveness of the bioactive metabolite produced by of $S$. aureofaciens at 1:5 concentrations against vegetative buds malformation disease of mango seedlings under artificial infested conditions were determined (Haggag et al., 2014)

\section{Integration of Management Measures}

Integrated management practices includes sanitary pruning, incorporation of organic matter to the soil, control of vectors, irrigation management, balanced chemical fertilization, protection of new buds, weed control and promoting anticipated blooming (GIIM, 1998; Noriega et al., 1999) may keep the disease severity below those economic loss level.

\section{References}

Abou El-Dahab, MK, 1975. Correcting malformation symptoms on mango trees in Egypt by soil application of iron chelates. Egypt. J. Phytopath., 7: 97-99.

Ahmad, F, Hafiz, IA, Asi, AA, Ahmad S and Khan, M 2002. Mango Varietal Susceptibility to Malformation and its Control. Asian J. Plant Science 1(2): 158159.

Attiah, HH 1955. A new eriophyid mite on mango from Egypt. Bull. Sci. Ent. Egypt, 39: 379383.

Azzouz, S, Khalifa A, Hamdy, ZH and El-Masry, $H$ 1980. Effect of growth regulators on the malformed inflorescence and stunting growth of mango. Agric Res. Rev. 58 (3):1.

Azzouz, S, Mostafa, HA Said, G and El-Masry, H 1984. Effect of some growth regulators on mango malformation. Agric. Res. Rev. 62, 181.

Badiyala, SD and Lakhanpal, SC 1990. Reaction of some mango cultivar to floral 
malformation under paonta valley conditions of Himachal pradesh. South Indian Hortic., 38: 152-153.

Beniwal, SPS and Bhatnagar, SS 1975. Annual Research Report. GBPUA and T, Pantnagar, pp: 1974-1975.

Bhatnagar, SS and Beniwal, SPS 1977. Involvement of Fusarium oxysporum in causation of mango malformation. Plant Dis. Reptr., 61: 894-898.

Bindra, OS and Bakhetia, DRC 1971. Investigations on the etiology and control of mango malformation. Indian J. Hort., 28: 8085.

Britz H, Steenkamp ET, Coutinho TA, Wingfield BD, Marasas WFO, Wingfield MJ (2002). Two new species of Fusarium section Liseola associated with mango malformation. Mycologia, 94: 722-730.

Burhan, MJ 1991. Mango malformation. Indian J. Hort., 28: 80-85.

Burns, W 1910. A common malformation of mango inflorescence. Poona Agric. Coll. Mag., 2: 38-39.

Burns, W and Parayag, SH 1920. The book of the mango. Department of Agriculture, Bombay Bull., pp: 103.

Campbell, CW, Marlatt, RB 1986. Current status of mango malformation disease in Florida. Proc. Interam. Soc. Trop. Hortic. 30:223-26

Chadha, KL, Pal, RN and Sahay, RK 1979. Effect of abscission promoting chemicals on deblossoming of mango. Indian J. Hort., 36: 238-244.

Chakrabarti DK, Kumar, R 1998. Mango malformation: role of Fusarium moniliforme and mangiferin. Agric. Rev., 19(2): 126-136.

Chakrabarti, DK 1996. Etiology and remedy of mango malformation. In: Disease Scenario in Crop Plants. Vol. 1- Fruits and Vegetables. Agnihotri, VP; Prakash, O; Kisbun, R; Misra, AK (Eds.). International Books and Periodicals Supply Service, Pitampura, Delhi, India. pp. 49-59.

Chakrabarti, DK 2011. Mango malformation. Springer (1): 148.

Chakrabarti, DK and Ghosal, S 1989. The disease cycle of mango malformation induced by Fusarium moniliforme var. subglutinans and the curative effects of mangiferin metal chilates. J. Phytopathol., 125: 238-246.
Chakrabarti, DK, Kumar R, and Ali, S 1997. Mango malformation: seasonal variation in Fusarium moniliforme population in relation to environmental factors, mangiferin content and flushing in Mangifera indica. Indian $\mathrm{J}$. Plant Prot., 25(2): 146-148.

Chib, HS, Aandotra, PS and Gupta, BR 1984. Survey report on the incidence and extent of mango malformation on mango growing areas of Jammu and Kashmir State. Indian J. Mycol. Plant Pathol., 14: 86-88.

Crespo MD, Altermann E, Olson J, Miller WG, Chandrashekhar, K and Kathariou, S 2016. Novel plasmid conferring kanamycin and tetracycline resistance in the turkey-derived Campylobacter jejuna strain 11601MD. Plasmid; 86:32-37.

Crookes, CA and Rijkenberg, FHJ 1985. Final research report on mango malformation. Rep. Mango Prod. Tech. Commun. 25 pp. Cited in Ref. 14

Darvas, JM 1987. Control of mango blossom malformation with trunk injection. S. Afr. Mango Growers' Yearbk. 7:21-24.

Davenport, TL 2009. "Reproductive physiology," in The Mango, Botany, Production and Uses, 2nd Edn, ed. Litz R. E. (Seattle, WA: CAB International), 97-169.

EI-Beltagy, MS, EI-Ghandour, MA and EIHanawi, 1980. Effects of Bayfolan and some growth regulators on modifying flowering and the incidence of flowering malformation of mango ( $M$. indica L.). Egyptian J. Hort., 6: 125-135.

Flechtmann, CHW, Kimati, H, Medcalf, JC and Ferre, J 1970. Preliminary observations of mango inflorescence malformation and the fungus, insects and mites associated with it. Anis da Escola Superior de Agriculture Luiz de Querioz, 27: 281-285.

Freeman S, Shtienberg D, Maymon M, Levin AG, Ploetz RC.2014. New insights into mango malformation disease epidemiology lead to a new integrated management,

Freeman, S, Maimon, M and Pinkas, Y 1999. Use of GUS transformants of Fusarium subglutinans for determining etiology of mango malformation. Phytopathology, 89: 456-460.

Freemana, S, Gamliel-Atinsky, E, Maymon, M, Youssef, S and Shtienberg, D 2015. Mango 
Malformation Disease: Etiology, Epidemiology and Management. Acta horticulturae - Proc. Xth Intl. Mango Symposium Eds.:J.J. Espinal et al., Acta Hort. 1075, pp, 207-214.

Freemana, S, Maymona, M, Biton, A, and Shtienberga D 2014. Management of mango malformation disease based on a novel strategy of timing of fungicide applications combined with sanitation. Asian journal of plant science.; 61:84-91.

Gamliel-Atinsky E, Freeman S, Sztejnberg A, Maymon M, Ochoa R, Belausov E. 2009a . Interaction of the mite Aceria mangiferae with Fusarium mangiferae, the causal agent of mango malformation disease. Phytopathology. ; 99:152-159.

Garcia Lopez Elvis, Mora-Aguilera Antonio, Nava-Diaz Cristian, Villegas-Monter Angel, Tovar-Pedraza Juan, Andreas-Serra. 2016. First Report of Fusarium pseudocircinatum Causing Mango Malformation Disease in Dominican Republic. Plant Disease, 2016, 100. 10.1094/PDIS-12-15-1397-PDN.

Giani, MA, 1965. Malformation of mango inflorescence. W. Pak. J. Agric. Res., 3: 248251.

GIIM (Grupo Interdisciplinario De Investigación En Mango). 1998. El Mango y su Manejo Integrado en Michoacán. Colegio de Posgraduados. Montecillos, Texcoco, México, pp.55.

Haggag Wafaa, Hazza M, Sehab A, Abd ElWahab M 2010. Epidemiology and the Association of the Fusarium Species with the Mango Malformation Disease in Egypt, Nature and Science, 8(4): 128-135.

Haggag, Wafaa and Radwan EL-Sehemy E, 2014.Screening of Marine Actinomycetes for their Antimicrobial and Antifungal Activities in Egypt, Int J Pharm Bio Sci., 5(4): 527536.

Hassan, AS 1944. Notes on Eriopyes mangiferae. Bull. Soc. Fouad. Entomol., 28: 179-180.

Hernández Delgado PM, Aranguren M, Reig CP, Fernández Galván D, Mesejo C, Martínez Fuentes A 2011. Phenological Growth Stages of Mango (Mangifera indica L.) according to the BBCH Scale. Scientia Horticulturae. 2011; 130:536-540

Hiffny, HAA, El-Barkouki, M and El-Banna, GS
1978. Morphological and physiological aspects of the floral malformation of mangoes. Egypt. J. Hort., 5: 43-53.

Hifny, HAA, EL-Barkouki, M and EL-Banna, GS 1978. Morphological and physical aspects of the floral malformation in mangoes. Egypt. J. Hort., 5:43-53.

Iqbal, Z, Rahman, UM, Dasti, AA, Saleem, A and Zafar, Y 2006. RAPD of Fusarium isolates causing Mango malformation disease in Pakistan. World J. Microb. Biotechnol., 22: 1161-1167.

Ishfaq A. Hafiz, Saeed Ahmad, Nadeem A, Abbasi , R, Anwar, Z.A. Chathaand A.G. Grewal. 2008. Intensity of panicle malformation in mango (Mangifera indica L.) Varieties. Pak. J. Agri. Sci., Vol. 45(4): 418-423.

Iyer, CPA, Schnell, RJ 2009. Breeding and genetics: The Mango: Botany Production and Uses. 2nd ed. R. E. Litz, ed. CAB International, Wallingford Oxon, UK. Pp 6796

Jagirdar, SAP, Jafri, NR 1966. Malformation of mango inflorescence. Agric. Pak. 17:351-57.

Kanwar, JS and Nijjar, GS 1979. Some observations on mango malformation. Proceedings of the Research Report Mango Workers Meeting, May 2-5, Goa, India, pp: 415-419.

Kausar, AG 1959. Malformation in inflorescence of mango. Punjab Fruit J., 22: 19-21.

Khan, MD and Khan, AH 1960. Some chemical studies on malformation of mango inflorescence in West Pakistan. Punjab Hort. J., 3: 229-234.

Khan, MD and Khan, AH 1963. Some chemical studies on malformation of mango inflorescence in West Pakistan. Punjab Hortic. 1. 3:229-34

Khaskheli, MI, Pathan, MA, Jiskani, MM, Wagan, $\mathrm{KH}$ and Goswami, SP 2008. Survey, Intensity, and varietal response of mango malformation disease in different mango orchards of Sindh , Pakistan. Pak. J. Agril. , Agril. Engg. and Vet. Sci., 24 (1): 53-56.

Khurana, AD and Gupta, OP 1973. Mango malformation in India. Pesticides, 7: 12-13.

Kulkarni, V 1979. Mango malformation at sangareddy (Andhra Pradesh). Res. Rep. Mango Workers Meeting, Goa, pp: 401-405.

Kumar R and Chakrabarti, DK (1997). Spatial 
patterns of spread of floral malformation of mango. Acta Hortic., 455: 600-608.

Kumar, J and Beniwal, SPS 1992. Mango Malformation. In: Plant Diseases of International Importance, Diseases of Fruit Crops, Kumar, J., H.S. Chaube, U.S. Singh and A.N. Mukhopadhyay (Eds.). Vol. III. Prentice Hall, New York, pp: 456.

Kumar, J, and Beniwal, SPS 1991. Mango malformation. Pages 357-393 in: Plant Diseases of International Importance. Vol. III. Diseases of Fruit Crops. J. Kumar, H. S. Chaube, U. S. Singh, and A. N. Mukhopadhyay, eds. Prentice Hall, Englewood Cliffs, NJ. 30.

Kumar, J, Singh, US and Beniwal, SPS 1993. Mango malformation: One hundred years of research. Ann. Rev. Phytopathol., 31: 217232.

Kumar, P, Misra AK and Modi DR 2011. Current status of mango malformation in India, Asian J Plant Sci., 10(1), 2011, 01-23.

Kumar, P, Misra, AK and Modi, DR (2011). Current status of mango malformation in India, Asian J. Plant Sci., 10: 1-23.

Kumar, R and Chakarabarti, DK (1997). Assessment of loss in yield of mango (Mangifera indica) caused by mango malformation. Indian J. Agric. Sci., 67: 130131.

Kvas, M, Steenkamp, ET, Al-Adawi, AO, Deadman, ML, Al-Jahwari, AA and Marasas, WFO 2008. Fusarium mangifarae associated with mango malformation in Sultanate of Oman. Eur. J. Plant Pathol., 121: 195-199.

Labuschang, TI, Joubert, MH and Steyn, A, 1993. Role of the mango bud mite, Aceria mangefera (Sayed) in mango malformation. Inlightingsbullwtin-Inst. Trop. SubtropieseGewaise, 246: 19-24.

Lahav,C, Sztejnberg, A, Maymon, M, Danisov, Y and Freeman, S 2001. Mango malformation disease: presence and identification of the casual organism Fusarium subglutinans in main branches of mature trees and saplings grafted with infected scions, and importance of sanitation treatments in orchards. AlonHanotea, 55: 301-304.

Liew, ECY, Laurence Matthew, Pearce Ceri, Shivas Roger, Johnson Greg, Tan Yu Pei
2016. Review of Fusarium species isolated in association with mango malformation in Australia. Australasian Plant Pathology, 2016. 45. 10.1007/s13313-016-0454-z.

Lima CS, Monteiro JHA, Crespo NC, Costa SS, Leslie, JF and Pfenning LH 2009. VCG and AFLP analyses identify the same groups in the causal agents of mango malformation in Brazil. Eur. J Plant Pathol. ; 123:17-26.

Lima CS, Pfenning LH, Costa SC, Abreu LM and Leslie JF.2012. Fusarium tupiense sp. nov. a member of the Gibberella fujikuroi complex that causes mango malformation in Brazil. Mycologia.; 104:1408-1419.

López-Estrada, ME, Noriega-Cantú,DH,OteroColina,G and Gutiérrez-Reyes, G 2005. Orchard management and sanitary pruning on the incidence of mango malformation. Revista Chapingo. Serie horti., 11:113-120.

Lu, P and Chacko, EK 2000. Effect of water stress on mango flowering in low latitude tropics of Northern Australia. Acta Hortic. , 509:283-290.

Magaritha Schoeman H, Ncobile Zulu B, André Botha F and Frikkie Calitz J. 2018. Integrated control of mango blossom malformation in South Africa, South African Journal of Plant and Soil, DOI: 10.1080/02571862.2018.1484 190.

Mahrous, HAH 2004. Effect of spraying some chemical substances and a fungicide on floral malformation disease in mango. Acta Hort., 645: 481-486.

Majumder, PK and Diware, DV1989. Studies on horticultural aspects of mango malformation. Acta. Hort., 231:840 - 845.

Majumder, PK and Sharma, DK 1990. Mango. In: Fruits: Tropical and Sub-Tropical, Bose, T.K. (Ed.). Naya Prakashan Pvt. Ltd., Calcutta, pp: 1-62.

Majumder, PK and Sinha, GC 1972. Seasonal variation in incidence of malformation in Mangifera indica L. Acta Hort., 24: 221-223.

Majumder, PK, Singh MP and Singh, RN 1976. Improved productivity of malformed mango trees. Indian J. Hort., 20: 7-8.

Majumder, PK, Sinha GC and Singh, RN 1970. The effect of exogenous application of Alfanapthyl-acetic acid on mango, (Mangifera indica L.) malformation. Indian J. Hort., 20: 130-131. 
Mallik, PC 1959. Mango malformation. Proceedings of the ICAR Seminar on Diseases of Horticultural Plants, June 10-15, Shimla, pp: 107-109.

Mallik, PC 1963. Mango malformation-symptoms, causes and cure. Punjab Hort. J., 3: 292-299.

Malo, SE and McMillan Jr., RT 1972. A disease of Mangifera indica L. in Florida similar to mango malformation. Florida State Hort. Soc., 85: 254-268.

Martin-Preveli, P., J. Marchal and V. Furon, 1975. A case of zink deficiency in mango. Fruits, 30: 201-201.

Meah, B and Khan, AA 1992. Mango diseases in Bangladesh. Proceedings of the 4th International Mango Symposium, July 5-10, Miami, pp: 20-20.

Mehta, NJ, Sandooja, JK, Madaan, RL and Yamdagni, R 1986. Role of different chemicals in mango malformation and related physiological factors. Pesticides, 20: 17-18.

Minessey, FA, Biely MP and El-Fahal, A 1971. Effect of iron chilates in correcting malformation of terminal bud growth in mango. Sudan Agric. J., 6: 71-74.

Mishra, KA 1976. Studies on bearing behaviour of Mangifera indica L. and its malformation. $\mathrm{Ph}$.D. Thesis, PAU, Ludhiana, India.

Mishra, SP, 2004. Studies on mango malformation. Proceedings of the 16th Group Workers Meeting on Subtropical Fruits, May 13-15, APAU, Hyderabad, pp: 250-253.

Muhammad Azam, Rashad Qadri, Muhammad Imran Khan, Mumtaz Khan Naheed Akhtar, Nazar Hussain Khan and Chaudary Muhammad Ayub. 2020. Impact of fertilizer combination on malformation physiology of mango panicles (Mangifera indica L.) cv Dusheri. Pure and App. Biol.; 9(1): 626-634.

Muhammad, F, Ibrahim, F, Pervez MA (1999). Effect of fungicides on mango malformation. Pak. J. Biol. Sci., 2: 772-773.

Mukehrjee SK, Litz RE 2011. Introduction: botany andimportance. In: Litz RE, Ed. The Mango: Botany,Production and Uses. Wallingford, UK: CABI, 1-18.

Narasimhan, MJ 1954. Malformation of panicles in mango incited by species of Eriophyes. Curr. Sci., 23: 297-298.
Narasimhan, MJ 1959. Control of mango malformation disease. Curro Sci. 28:254-55.

Narayanan, E.S. and S. Ghai, 1961. Some new records of mites associated with malformation in mango trees in India. Proc. Indian Sci. Cong., 3: 502-502.

Narayanan, ES and Ghai, S 1962. Some new records and a new species of mites associated with malformation of mango trees in India. Proc. Nat. Inst. Sci. India, 29B: 535-546

Nath, R., Kamal Wanshi, RS and Sachan, IP 1987. Studies on mango malformation. Indian J.Mycol. Plant Pathol., 17: 29-33.

Negi, SS 2000. Mango production in India. Acta Hortic., 509: 69-78.

Nirvan, RS 1953. Bunchy top of young mango seedlings. Sci. Cult., 18: 335-336.

Noriega-Cantú DH, Téliz D, Mora-Aguilera G, Rodríguez-Alcazar J, Zavaleta-Mejía E, Otero-Colinas G. 1999. et al. Epidemiology of mango malformation in Guerrero, México, with traditional and integrated management. Plant Disease. ; 83:223-228.

Nunez, Elisea, R, Becerril, Roman, $\mathrm{AE}$ and Montenegra, Diaz, D 1986. Effects of ethrel on flowering in mango cv. American. Soc. Hort. Sci. 23, 138.

Otero-Colina G, Rodriguez-Alvarado G, Fernandez-Pavia S, Maymon M, Ploetz RC, Aok T. 2010. et al. Identification and characterization of a novel etiological agent of mango malformation disease in México, Fusarium mexicanum sp. Nov. Phytopathology.; 100:1176-84.

Padron Soroa, J 1983. Factors responsible for low yield of mango. Bal.Reseiias Prot. Plantas No.10. 37 pp.

Pandey, D and Pandey, SN 1997. Effect of growth regulators and zinc sulphate on floral malformation in mango (Mangifera indica L.). Proceedings of the National Seminar ISPP, March 19-21, IARI, New Delhi, pp: 94-94.

Pandey, RM, Rao MM and Pathak, RA 1977. Biochemical changes associated with floral malformation in mango. Scientia Hortic., 6: 37-44.

Pandey, RM, Singh, RN and Sinha, G. 1973. Usefulness of ethereal in regulating flower bearing in mango. Sci. Cult., 39: 148-150. 
Pinkas, Y and Gazit, S 1992. Mango malformation control strategies. Proceedings of the 4th International Mango Symposium, July 5-10, Miami, pp: 22-22.

Ploetz RC (1994). Distribution and prevalence of Fusarium subglutinans in mango trees affected by malformation. Can. J. Bot., 72: 7-9.

Ploetz RC 2001. Malformation: a unique and important disease of mango, Mangifera indica L. In: Summerell BA, Leslie JF, Backhouse D, Bryden WL, eds. Fusarium: Paul E. Nelson Memorial Symposium. St Paul, MN, USA: APS Press, 233-47.

Ploetz RC, Freeman S 2009.Foliar, floral and soilborne diseases. In: Litz RE, Ed. The Mango: Botany, Production and Uses. Wallingford, UK: CABI, 231-302.

Ploetz, RC 2004. The Major Diseases of Mango: Strategies and Potential for Sustainable Management. Acta Hort., 645: 137-150.

Ploetz, RC and Gregory, N 1993. Mango malformation in Florida: Distribution of Fusarium subglutinans in affected trees, and relationships within and among strains from different orchards. Acta Hort,. 341:388-394.

Ploetz, RC, Zheng, QI, Vazquez, A and Abdel Sattar, MA 2002. Current status and impact of mango malformation in Egypt. Int. J. Pest Manage. 48: 279-285.

Popenoe W 1932. Manual of tropical and subtropical fruits. Macmillan Co., New York.

Prakash, O and Srivastava, KC 1987. Mango Diseases and their Management - A World Review. Tommorow's Printer, New Delhi.

Prasad, A, Nirwan RS and Singh, S 1972. Mango malformation: A review of work done at Horticultural Research Institutes, Saharanpur (U.P.). Acta Hort., 24: 227-229.

Prasad, A, Singh, H, Shukla, TN 1965. Present status of mango malformation disease. Indian J. Hortie. 22:254-65.

Purseglove, JW1972. Mangoes west of India. Acta Horticulturae. 24:107-174.

Puttarudriah, M. and Channa Basavanna, GP 1961. Mango bunchy top and eriophyid mite. Curr. Sci., 30: 114-115.

Rajan, S, 1986. Biochemical basis of mango (Mangifera indica L.), malformation. Ph.D. Thesis, IARI, New Delhi.
Ram, RB, Singh, BP and Singh, SP 1990. Studies on malformation of mango (Mangifera indica L.) inflorescence with reference to varieties and age of the tree. Hort. J., 3: 3136.

Ramirez KS, Leff JW, Barberán A, Bates ST, Betley J and Crowther TW 2014. Biogeographic patterns in belowground diversity in New York City's Central Park are similar to those observed globally. Proc. R. Soc. B. 281:214

Salazar-Garcia, S 1995. Mango malformation: A review Rev. Maxicana de Fitopatologia 13: 64-75.

Sao-Jose AR, Souza SE, Vega-Pena A, Ataide EM (2000). Incidence and severity of mango malformation in Bahia State. Brazil. Acta Hort., 509: 765-767.

Sattar, A 1946. Diseases of mango in the Punjab. Punjab Fruit J. 10:56-58

Sayed, MT 1946. Aceria mangiferae nov. sp. Bull. Soc. Ent., 30: 7-10.

Schlosser, SE 1971. Mango malformation: Symptoms, occurrence and varietal susceptibility. Plant Prolect. Bull. FAO. 19: 12-14.

Scholefield, PB, Oag DR and Sedgley, M 1986. The relationship between vegetative and reproductive development in mango in Northern Australia. Aust. J. Agric. Res., 37: 425-433.

Schwartz, A, 1968. A new mango pest. Farming South Afr., 9: 7-7.

Senghor AL, Sharma K, Kumar PL and Bandyopadhyay, R 2012. First report of mango malformation disease caused by Fusarium tupiense in Senegal. Plant Dis. 96:1582

Sharma R, Pandey SK and Sharma TR, 2015. Influence of soil moisture on growth and nutrient content in healthy and malformed panicles of mango varieties. Indian $\mathrm{J}$. Horticulture, 72(1): 133-138.

Sharma, IM and Badiyala, SD 1990. Incidence of mango malformation in different locations of Himanchal Pradesh. Indian J. Mycol. Plant Pathol., 20: 179-181.

Shawky, I, Zidan, Z, El-Tomi A and Dahshan, DI 1978. Effect of GA sprays on time of blooming and flowering malformation in Taimour mango. Egypt. J. Hortic., 5: 123- 


\section{2.}

Shawky, I, Zidan, Z, El-Tomi, A and Dashan, DI 1980. Flowering malformation in relation to vegetative growth of Taimour mango. Egypt. J. Hort., 7: 1-8.

Singh, BN and Chakrabarti, SC 1935. Observations on a disease of mango at banaras. Sci. Cult., 1: 294-295.

Singh, CP and Ram, S (1997). Effect of irrigation on flowering, fruiting and malformation in mango. Acta Hort. 455:543-546

Singh, CP, Singh, IS and Singh, AK (1992). Certain physiological aspects of malformation in mango (Mangifcra indica L.). Acta Horti. 296: 3-4.

Singh, L, Bajwa, BS and Khan, AA 1940. Mangoes. Punjab Fr. J., 4: 678-678

Singh, LB, Singh, SM, Nirvan, RS 1961. Studies on mango malformation: Review, symptoms, extent, intensity and cause.Hortie. Adv. 5:197-207.

Singh, LS, Singh, SM and Nirvan, RS 1961. Studies on mango malformation review, symptoms, extent, intensity and cause. Hort. Adv., 5: 197-207.

Singh, ND, Singh, AR, Singh, B and Singh, RK 1999. Effect of age and cultivars on the susceptibility of mango malformation. Adv. Hortic. For., 6: 9-21.

Singh O.P, Ushaa K, Sabokia E, Srivastava M, Dahujac A, Singh B.2012. Enzymatic reactive oxygen species (ROS) scavenging system in mango varieties resistant and susceptible to malformation. Scientia Hort. 138:81-89.

Singh, P, Singh, SP, Singh, Moharana, DP and Singh, AK 2017. A Critical Overview on Various Physiological Disorders of Mango (Mangifera indica L.). Trends in Biosciences 10(28), 5913-5916.

Singh, RN, Majumder, PK Shrama, DK, Sinha, GC and Bose, PC 1974. Effects of deblossoming on productivity of mango. Sci. Hort., 2: 399-403.

Singh, RR and Rajput, CBS 1976. Effect of various concentrations of zinc on vegitative growth, characters, flowering, fruiting and physiochemical composition of fruits in mango. Haryana J. Hort. Sci., 5: 10-15.

Singh, S, Sengupta, BN, Roychaudhary, N and Singh, S 1994. Intensity and susceptibility to floral malformation of some important mango cvs. Hort. J.; 17(2): 97-101.

Singh, SM 1955. Malformation diseases of mango (Mangifera indica Linn.). Curr. Sci., 24: 168-169.

Singh, VK, Saini, JP, Misra AK and Pandey, D 1999. Role of temperature on the occurrence of mango floral malformation in Kumaon Hills. Biol. Memoirs, 25: 47-49.

Singh, Z and Dhillon, BS 1986. Effect of plant growth regulators on floral malformation, flowering productivity and fruit quality of mango (Mangifera indica L.). Acta Hort., 175: 315-319.

Singh, Z, Dhillon, BS and Arora, CL 1991. Nutrient levels in malformed and healthy tissue of mango (Mangifera indica L.). Plant Sci., 133: 9-15.

Singh, Z, Singh, L, Arora, CL and Dhillon, BS 1994. Effect of cobalt, cadmium, and nickel as inhibitors of ethylene biosynthesis on floral malformation, yield, and fruit quality of mango. J Plant Nutri. 17: 1659-1670.

Singh, Zora, Lakhvir Singh and Dhillon, BS (1994). Micro-nutrient levels in malformed and healthy tissues of mango. Indian Journal of Horticulture 51(4):

Sirohi,SC, Prakash, S, Rana, P and Singh, R 2009. Response of mango malformation to severity of malformed panicle bearing shoot pruning. Indian J. Hort., 66: 393-395.

Soni, N, Patel, N, Pandey, SK and Tiwari, P 2013. Influence of directions on malformation incidence in different mango (Mangifera indica L.) cultivars. Flora and Fauna; 19 (2):.267-276.

Srivastava , RP 1998. Mango malformation . In: Srivastava R.P. (ED) Mango Cultivation, International Book Distributing Co. Lucknow , India pp: 363-407.

Summanwar, A. S., Raychaudhuri, S. P., Pathak, S. C. 1966. Association of fungus Fusarium moniliforme Sheld. With the malformation in mango. Indian Phytopathol. 19:227-28

Summanwar, AS 1967. Mango malformation: Serious economic consequences. Indian Hort., 11: 12-16.

Summanwar, AS and Raychaudhuri, SP 1968. The role of eriophyid mite (Aceria mangiferae) in the causation of mango malformation. Indian Phytopathol., 21: 463-464. 
Tahir,F.M.; M. Ibrahim and Kamran Hamid, 2003. Effect of Drought Stress on Vegetative and Reproductive Growth Behaviour of Mango (Mangifera indica L.). Asian Journal of Plant Sciences, 2: 116-118.

Thakur, AS, Vaishampayan, SM, Shukla, A 2000. Effect of varieties, nutrients and direction on the incidence of floral and vegetative malformation in grafted mango. Crop Research, 20 (3): 494-499.

Tripathi, RD 1955. Malformation disease of the mangu as related to deficiency of mineral nutrients. Indian J. Hortie. 12:173-79

Varma, A 1983. Mango Malformation. In: Exotic Plant Quarantine Pests and Procedures for introduction of Plant Materials, Singh, K.G. (Ed.). Asean Plant Quqrantine Centre and Training Institutes, Serdang, Selangur, Malaysia, pp: 173-188.

Varma, A, 1983. Mango Malformation. In: Exotic Plant Quarantine Pests and Procedures for introduction of Plant Materials, Singh, K.G. (Ed.). Asean Plant Quqrantine Centre and Training Institutes, Serdang, Selangur, Malaysia, pp: 173-188.

Varma, A, Lele, VC and Goswami, BK 1974. Mango Malformation. In: Current Trends in Plant Pathology, Raychaudhury, S.P. and J.P. Varma (Eds.). Lucknow University, Uttar Pradesh, India, pp: 196-208.

Varma, A, Lele, VC, Majumder, PK, Ram, A and Sachchidananda J $1969 . \quad$ Mango malformation. Proceedings of the ICAR Workshop on Fruit Research, April 28-30, Ludhiana, India, pp: 1-1.
Varma, A, Lele, VC, Raychaudhuri, SP, Ram, A and Sang, A 1974. Mango malformation: A fungal disease. Phytopath Z., 79: 254-257.

Varma, A, Raychaudhury, SP, Lele, VC and Ram, A 1969. Towards the understanding of the problem of mango malformation. Int. Symp. Mango, pp: 3.

Varma, A., Lele, VC, Raychaudhuri, SP and Ram, A 1971. Preliminary investigations on epidemiology and control of mango malformation. Proc. Indian Nat. Sci Acad., 37: 291-300.

Watt, G 1891. A Dictionary of Economic Products of India, p. 149. Calcutta, India: Gov. Printing Press.

Yadava, RBR and Singh, VK 1995. Extent of floral malformation and its relationship with physiochemical componentsbin mango cultivars. Indian J. Plant Physiol., 38: 328330.

Youssef, SA, Maymon, M, Zveibil, A, KleinGueta, D, Sztejnberg, A, Shalaby, AA and Freeman, S 2007. Epidemiological aspects of mango malformation disease caused by Fusarium mangiferae and source of infection in seedlings cultivated in orchards in Egypt. Plant Pathol., 56: 257-263.

Zafar Iqbal, Naeem Akhtar, Muhammad Usman Ghazanfar, Sher Muhammad Shehzad, Salman Ahmad, Muhammad Asif. 2011. Management of mango malformation through physical alteration and chemical spray. African Journal of Agricultural Research. 6:1897-1901.

\section{How to cite this article:}

Rajnee Sharma, Ashish Sharma, Jai Singh and Sharma, T. R. 2020. Malformation: Impending Danger in Mango Cultivation. Int.J.Curr.Microbiol.App.Sci. 9(11): 14-30. doi: https://doi.org/10.20546/ijcmas.2020.911.003 